\title{
Cereal- and Fruit-Based Ethiopian Traditional Fermented Alcoholic Beverages
}

\author{
Eskindir Getachew Fentie ${ }^{1,2}{ }^{-0}$, Shimelis Admassu Emire ${ }^{3}$, Hundessa Dessalegn Demsash ${ }^{3}$ (i), \\ Debebe Worku Dadi ${ }^{4}$ (I) and Jae-Ho Shin ${ }^{2, *}$ (D) \\ 1 College of Biological and Chemical Engineering, Addis Ababa Science and Technology University, \\ Addis Ababa 16417, Ethiopia; eskench@gmail.com \\ 2 Department of Applied Biosciences, Kyungpook National University, Daegu 41900, Korea \\ 3 School of Chemical and Bio-Engineering, Addis Ababa Institute of Technology, Addis Ababa University, \\ P.O. Box 385, King George VI Street, Addis Ababa 16417, Ethiopia; shimelisemire@yahoo.com (S.A.E.); \\ hundessad@gmail.com (H.D.D.) \\ 4 Department of Food Engineering and Postharvest Technology, Institute of Technology, Ambo University, \\ Ambo 2040, Ethiopia; debeworku2010@gmail.com \\ * Correspondence: jhshin@knu.ac.kr; Tel.: +82-53-950-5716
}

Received: 29 October 2020; Accepted: 28 November 2020; Published: 1 December 2020

\begin{abstract}
Traditional fermented alcoholic beverages are drinks produced locally using indigenous knowledge, and consumed near the vicinity of production. In Ethiopia, preparation and consumption of cereal- and fruit-based traditional fermented alcoholic beverages is very common. Tella, Borde, Shamita, Korefe, Cheka, Tej, Ogol, Booka, and Keribo are among the popular alcoholic beverages in the country. These beverages have equal market share with commercially produced alcoholic beverages. Fermentation of Ethiopian alcoholic beverages is spontaneous, natural and uncontrolled. Consequently, achieving consistent quality in the final product is the major challenge. Yeasts and lactic acid bacteria are the predominate microorganisms encountered during the fermentation of these traditional alcoholic beverages. In this paper, we undertake a review in order to elucidate the physicochemical properties, indigenous processing methods, nutritional values, functional properties, fermenting microorganisms and fermentation microbial dynamics of Ethiopian traditional alcoholic beverages. Further research will be needed in order to move these traditional beverages into large-scale production.
\end{abstract}

Keywords: traditional alcoholic beverage; Ethiopia; processing; physicochemical; fermentative microorganisms

\section{Introduction}

Worldwide production and consumption of fermented beverages has a long history, and is believed to have started around $6000 \mathrm{BC}[1,2]$. Production techniques and consumption of these traditional beverages are very localized [3]. Ethiopia, like other parts of the world, produces and consumes a significant volume of traditional alcoholic beverages (Table 1). About eight million hectoliters of Ethiopian traditionally fermented alcoholic beverages are produced yearly. Commercially and traditionally produced alcoholic beverages have an almost equal market share [4] and annual per capital pure alcohol consumption in the country is about $2 \mathrm{~L}$ [5].

Traditional alcoholic drinks are widely produced and consumed in Asia and Africa [6]. Rwanda's ikigage [7], Nigeria's oti-oka [8], Uganda's kwete [9], Kenya's Busaa [10], Korea's makgeolli [11] and Mexico's pulque [12] are among the most common traditional alcoholic beverage that are consumed and produced in each respective country. 
In Ethiopia, Tella [1], Borde [13], Shamita [14], Korefe [15], Keribo [16], Cheka [17], Tej [18], Ogol [19] and Booka [20] are very popular indigenous fermented alcoholic beverages. The total alcohol content of these beverage is in the range of $1.53-21.7 \%(v / v)[18,20]$. All of these Ethiopian alcoholic beverages are produced at a small scale and sold by local alcohol venders from their homes. These traditional alcoholic beverages are classified under the category of acid-alcohol fermentation systems [21].

Scholars define wine and beer based on various perspectives. For instance, Herman [22] defined wines as alcoholic beverages made from sound ripe grapes, whereas Pederson [23] defined alcoholic beverages based on the kind of substrates: beers are produced from cereals whereas wines are produced from fruits. In addition, Steinkraus [24] defined wine as an alcoholic beverage that uses sugar as the principal source of fermentable carbohydrate. According to Steinkraus [24], beverages made from honey, sugar cane and palm are classified under the category of wine. Hence, Tej, Ogol and Booka can alternatively be called wines, since honey is used as a major substrate for the fermentation process.

"Gesho" (Rhamnus prinoides L.), also known as "dog wood", is the most common ingredient used to prepare Ethiopian alcoholic beverages, primarily as a flavoring and bittering agent. The substance $\beta$-sorigenin-8-O- $\beta$-D-glucoside ("geshoidin") is the naphthalenic compound responsible for imparting bitterness $[25,26]$. In addition to this, it is also a source of fermentative microorganisms and plays a significant role during fermentation in regulating the microbial dynamic [27].

Due to the absence of standardized processes, back-slopping, and starter culture, Ethiopian beverages often have poor quality and failure to achieve their objective [28]. Moreover, preparation of these fermented alcoholic beverages is time-consuming and laborious [29]. As far as we know, this review is the first of its kind to address the research trends, significant research gaps and directions for future research outputs on Ethiopian traditional fermented alcoholic beverages. In particular, the raw materials, processing methods, physicochemical properties, nutritional values, functional properties, responsible fermenting microorganisms, fermentation microbial dynamics and storage stability of Ethiopian alcoholic beverages are the key points reviewed in the paper.

Table 1. Summary of cereal- and fruit-based Ethiopian traditional fermented alcoholic beverages.

\begin{tabular}{|c|c|c|c|c|}
\hline Category of Beverages & Beverages & Raw Materials & $\begin{array}{c}\text { Prominent Production and } \\
\text { Consumption Regions }\end{array}$ & References \\
\hline \multirow{4}{*}{ Beers } & Tella & $\begin{array}{l}\text { Barley (Hordeum vulgare L.), wheat } \\
\text { (Triticum aestivum L.), maize (Zea mays } \\
\text { L.), finger millet (Eleusine coracana L.), } \\
\text { sorghum (Sorghum bicolor L.), "teff" } \\
\text { (Eragrostis tef L.), "gesho" } \\
\text { (R. prinoides) }\end{array}$ & $\begin{array}{c}\text { Amhara, Oromia, Tigray, SNNP, } \\
\text { Addis Ababa }\end{array}$ & {$[30,31]$} \\
\hline & Shamita & $\begin{array}{l}\text { Roasted barley (H. vulgare) flour, salt, } \\
\text { linseed (Linum usitatissimum L.) flour, } \\
\text { chili pepper (Capsicum anпuиm) }\end{array}$ & SNNP, Addis Ababa & {$[13,33]$} \\
\hline & Cheka & $\begin{array}{l}\text { Sorghum (S. bicolor), maize (Z. mays), } \\
\text { finger millet (E. coracana), vegetables, } \\
\text { root of taro (Colocasia esculenta L.) }\end{array}$ & SNNP & {$[17,35,36]$} \\
\hline & Areke & $\begin{array}{l}\text { Barley (H. vulgare), "gesho" } \\
\text { (R. prinoides), sorghum }\end{array}$ & $\begin{array}{c}\text { Amhara, Oromia, Tigray, SNNP, } \\
\text { Addis Ababa }\end{array}$ & [37-39] \\
\hline \multirow{3}{*}{ Wine } & $\mathrm{Tej}$ & Honey, "gesho" (R. prinoides) & $\begin{array}{c}\text { Oromia, Amhara, Tigray, } \\
\text { Addis Ababa }\end{array}$ & {$[18,39,40]$} \\
\hline & Ogol & $\begin{array}{l}\text { honey, barks of native tree } \\
\text { (Blighia unijungata L.) }\end{array}$ & Gambella (Majangir) & [19] \\
\hline & Booka & Honey, bladder of cow & Oromia (Gujii) & [20] \\
\hline
\end{tabular}




\section{Cereal-Based Traditional Alcoholic Beverages}

\subsection{Tella}

Tella is the most consumed traditional fermented alcoholic beverage in Ethiopia. It is the most popular beverage in the Oromia, Amhara and Tigray regions (Table 1). Barley, wheat, maize, millet, sorghum, "teff" (E. tef) and "gesho" leaves (R. prinoides) along with naturally-present microorganisms are the ingredients used to produce Tella [1]. Even though the volume of production and consumption is high, the fermentation process is still spontaneous, uncontrolled and unpredictable [41].

The Tella making process and its raw materials vary among ethnic groups and economic and traditional situations [37]. Although there are minor changes in the process in different localities, the basic steps are similar throughout the country. The making of "Tejet", "Tenses" and "Difdif" are the fundamental steps in the Tella preparation process [1].

The Tella making process starts by soaking the barley in water for about $24 \mathrm{~h}$ at room temperature to produce a malt, locally called "Bikil". After $24 \mathrm{~h}$, the moistened grain is covered by using fresh banana leaves and kept in a dry place for an additional three days [39]. Then, the germinated barley grain is sun-dried and ground to produce malt flour. At the same time "gesho" (R. prinoides) leaves and stems are sun-dried and ground. Then, "Bikil" flour and "gesho" powder are mixed with an adequate amount of water in a clean and smoked traditional bioreactor known as "Insera". This mixture is left to ferment for two days to form "Tejet" [31]. Subsequently, millet, sorghum and "teff" (E. tef) flours of equal proportion are mixed with water to form a dough. The dough is then baked to produced unleavened bread locally known as "ye Tella kita" [41], which is sliced into pieces and added to the earlier produced "Tejet". The mixture is then sealed tightly to ferment anaerobically for 5 to 7 days to turned into "Tenses" [30].

While the "Tenses" is fermenting, maize grain is soaked in water for about $3 \mathrm{~d}$, and then it is dried, roasted and ground to make a dark maize flour called "Asharo". "Asharo" is the main ingredient that determines the color of Tella [31]. "Asharo" is then added to the previously produced "Tenses" and fermented anaerobically for a period of 10 to 20 days. After this period of fermentation, a thick mixture locally called "Difdif" is formed. Water is added to "Difdif" and left to ferment for an additional 5 to $6 \mathrm{~h}$. Finally, solid residues are removed by filtration and served to consumers as Tella. In order to produce 25 to $28 \mathrm{~L}$ of pure Tella, $1 \mathrm{~kg}$ of "gesho" (R. prinoides) powder, $0.5 \mathrm{~kg}$ of "Bikil", $5 \mathrm{~kg}$ of "ye Tella kita", $10 \mathrm{~kg}$ of "Asharo" and $30 \mathrm{~L}$ of water are required [41].

Ingredients and utensils used to prepare Tella are the major source of microorganisms for the fermentation process [42]. As shown in Table 2, genera of Saccharomyces, Lactobacillus and Acetobacter are the most predominant fermenting microorganisms present in Tella $[1,30,41]$. The alcohol content and $\mathrm{pH}$ of Tella collected from different localities vary from 3.98-6.48\% $(v / v)$ and $1.52-4.99$, respectively [43]. The alcohol content of Tella is greater than that of Rwanda's ikigage [7] and is very much lower than Korean makgeolli [11]. The electric conductivity, salinity and total dissolved solids (TDS) of Tella are $2359 \mu \mathrm{s} / \mathrm{cm}, 1.2 \%$ and $1180 \mathrm{mg} / \mathrm{L}$, respectively [44].

Since the production of Tella is performed at the household level, it seriously lacks aseptic processing conditions. Consequently, the shelf life is no longer than 5 to 7 days at room temperature. Beyond that, the flavor becomes too sour to drink. Acetobacter species are mostly responsible for this sourness because they convert ethanol to acetic acid in the presence of oxygen [45]. 
Table 2. Physicochemical properties, microbial load, and storage stability of Tella.

\begin{tabular}{|c|c|c|c|}
\hline Area of Investigation & Shelf Stability, Microbial and Physicochemical Properties & Concluding Remarks & References \\
\hline $\begin{array}{l}\text { Storage stability, and microbial dynamics } \\
\text { for vacuum filtered (VF), pasteurized (P) } \\
\text { and control Tella }\end{array}$ & $\begin{array}{l}\text { - S. cerevisiae and Acetobacter xylinum (A. xylinum) are the } \\
\text { dominating microorganisms; } \\
\text { pH of control sample decreased, while VF and P pH samples } \\
\text { increased during storage time; } \\
\text { - Turbidity of the control sample increased, while VF and P } \\
\text { turbidity decreased or remained the same. }\end{array}$ & $\begin{array}{l}\text { Pasteurization is an efficient method to } \\
\text { extend the shelf life compared to } \\
\text { vacuum filtration }\end{array}$ & [1] \\
\hline Optimization of Tella production & $\begin{array}{l}\text { - } 3: 1 \text { (malt to "gesho" (R. prinoides)) showed lower } \mathrm{pH} \text { after } \\
\text { nine days of fermentation; } \\
\text { - Fermentation rate increased with increasing malt to "gesho" } \\
\text { (R. prinoides) ratio. }\end{array}$ & $\begin{array}{l}\text { The optimum fermentation process } \\
\text { parameters: } \\
\text { - Temperature }=20-25^{\circ} \mathrm{C} \text {, average; } \\
\text { - } \quad \mathrm{pH}=4.78 ; \\
\text { - Malt to "gesho" (R. prinoides) } \\
\quad \text { ratio = 1:3. }\end{array}$ & [46] \\
\hline $\begin{array}{l}\text { Isolation and characterization of } S . \\
\text { cerevisiae from Tella }\end{array}$ & $\begin{array}{l}\text { - } \quad \text { Six S. cerevisiae strains were isolated and } \\
\text { characterized phenotypically; } \\
\text { - } \quad \text { Isolates produce } 10-15 \% \mathrm{~mL} / \mathrm{L} \text { of absolute ethanol; } \\
\text { - } \quad \text { Isolates showed } 84 \% \text { of viability at higher } \\
\text { sugar concentration; } \\
\text { - } \quad \text { Isolates had an average } 65 \% \text { flocculation capacity. }\end{array}$ & $\begin{array}{l}\text { Isolated strains have a good fermentative } \\
\text { potential, especially for beer production }\end{array}$ & [30] \\
\hline $\begin{array}{l}\text { Physicochemical properties of fresh and } \\
\text { matured Tella }\end{array}$ & $\begin{array}{ll}\text { - } & \mathrm{pH} 4.67-3.87 ; \\
\text { - } & \text { Alcohol content }(\% v / v) 3.04-3.75 ; \\
\text { - } & \text { Specific extract } 1.0056-1.0037 ; \\
\text { - } & \text { Original extract } 7.50-7.27 ; \\
\text { - } & \mathrm{CO}_{2} \text { content }(\%) 0.24-0.034\end{array}$ & $\begin{array}{l}\text { - Alcohol content increases with } \\
\text { increasing maturation time; } \\
\text { - } \mathrm{pH}, \text { specific extract, original extract, } \\
\text { and } \mathrm{CO}_{2} \text { content decrease with } \\
\text { increasing maturation time. }\end{array}$ & [31] \\
\hline
\end{tabular}




\subsection{Borde}

Borde is a cereal-based Ethiopian traditional fermented low alcoholic beverage that uses maize (Z. mays), wheat (T. aestivum), finger millet (E. coracana) and sorghum (S. bicolor) interchangeably or sometimes proportionally as the main ingredients [29]. It is commonly produced and consumed in the southern and western part of Ethiopia. The local communities consider Borde as a meal replacement. Particularly, low-income local groups of the population may consume up to 3 L of Borde per day [47]. The nutritional value is high due to the high number of live cells present in freshly produced Borde [32].

The Borde making process starts with germinating barley grain by following the same procedure described for the Tella malt preparation process. This malt, a source of amylase enzymes, is ground to become a malt flour [33]. In parallel, maize grits are mixed with a proportional volume of water and fermented for about 44 to $48 \mathrm{~h}$ (Figure 1). The fermented blend is divided into three portions. Similar to Uganda's kwete [9], about $40 \%$ of the blend is roasted on a hot pan and a bread locally called "Enkuro" is produced. Then, the prepared "Enkuro" is mixed with malt flour and additional water and allowed to ferment for about $24 \mathrm{~h}$ in the same mixing tank [32]. The other $40 \%$ of the fermented maize grits are mixed with additional fresh maize flour and water. This mixture is shaped into a ball-like structure and cooked using steam to form "Gafuma" [29]. Subsequently, "Gafuma" is added to previously prepared "Tinsis" to become the thick brown mash called "Difdif" [13]. The remaining 20\% of the fermented maize grits are mixed with additional flour and water and boiled to form thick porridge. Then, the prepared porridge, extra malt, and water are mixed into the earlier produced "Difdif". Finally, the mixture is filtered and a small amount of water is added before serving to consumers as the final product Borde [33].

A good-quality Borde can be described as opaque, fizzy, of uniform turbidity, gray in color, with a thick consistency, a fairly smooth texture, and a flavor somewhere in the middle between sweet and sour [29]. The average $\mathrm{pH}$ values of Borde lie within the range of 3.6-4.1. The type of ingredients used and the processing conditions are the major causes for variation in the final product [32]. The conductivity, salinity and TDS values of Borde are $7139 \mu \mathrm{s} / \mathrm{cm}, 3.9 \%$, and $3830 \mathrm{mg} / \mathrm{L}$, respectively. As in Kenya's busaa [10], yeast and lactic acid bacteria are the dominant microorganisms in Borde. Around $10^{9} \mathrm{CFU} / \mathrm{mL}$ counts have been recorded for both mesophilic bacteria and lactic acid bacteria [47]. In addition, a $10^{5}-10^{7} \mathrm{CFU} / \mathrm{mL}$ yeast count has been reported for freshly prepared Borde (Table 3). Due to these high microorganism counts, Borde becomes unfit for consumption after $12 \mathrm{~h}$ of room temperature storage [29]. 


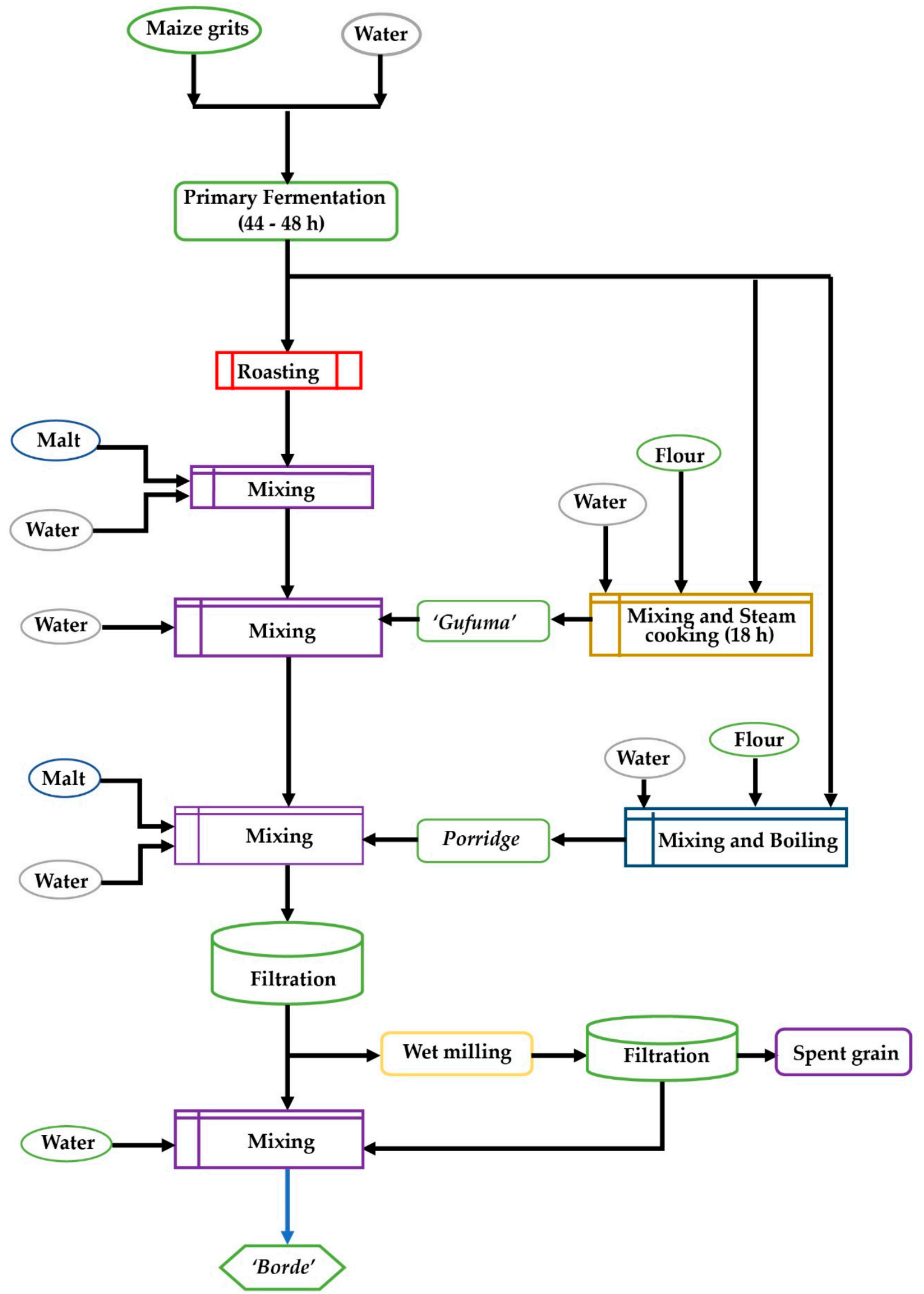

Figure 1. Borde processing flow chart [29]. 
Table 3. Processing methods and microbiological properties of Borde.

\begin{tabular}{|c|c|c|c|}
\hline Area of Investigation & Microbial Load, Microbial Dynamics, and Processing Methods & Concluding Remarks & References \\
\hline $\begin{array}{c}\text { Isolation and characterization of } \\
\text { lactic acid bacteria (LAB) involved in } \\
\text { Borde fermentation }\end{array}$ & $\begin{array}{l}\text { - Heterofermentative lactobacillus }(79.4 \%) \text { is the predominate } \\
\text { microorganism in Borde; } \\
\text { Dominant species are: Weissella confusa }(30.9 \%) \text {, Lactobacillus } \\
\text { viridescens, }(26.5 \%) \text {, Lactobacillus brevis }(10.3 \%) \text { and Pediococcus } \\
\text { pentosaceus }(7.4 \%) \text {. }\end{array}$ & $\begin{array}{l}\text { Dominant microorganisms have a potential } \\
\text { to be used as a starter culture }\end{array}$ & [13] \\
\hline $\begin{array}{l}\text { Antagonist effect of lactic acid } \\
\text { bacteria over pathogenic } \\
\text { microorganisms }\end{array}$ & $\begin{array}{l}\text { - At the beginning of fermentation Esherichia coli (E. coli } \\
\text { O157:H7), Staphylococcus aureus (S. aureus), Shigella } \\
\text { flexneri (S. flexneri) and Salmonella species counts are greater } \\
\text { than } 10^{7} \mathrm{CFU} / \mathrm{mL} \text {; } \\
\text { After } 16 \mathrm{~h} \text { of fermentation the count of Salmonella species is } \\
\text { less than } \log 2 \mathrm{CFU} / \mathrm{mL} \text {, and all pathogenic microorganisms } \\
\text { are below the detectable limit after } 24 \mathrm{~h} \text { of fermentation. }\end{array}$ & $\begin{array}{l}\text { Secondary metabolites of LAB have a } \\
\text { significant antimicrobial effect }\end{array}$ & [48] \\
\hline $\begin{array}{l}\text { Modified process technology for } \\
\text { Borde production }\end{array}$ & $\begin{array}{l}\text { - } \quad \text { Maize flour is substituted by maze grits; } \\
\text { - } \quad \text { Remove wet milling from last stage of the process. }\end{array}$ & $\begin{array}{l}\text { Borde making process can be simplified } \\
\text { without compromising quality }\end{array}$ & [47] \\
\hline $\begin{array}{c}\text { Survey on local methods of } \\
\text { processing and sensory analysis } \\
\text { of Borde }\end{array}$ & $\begin{array}{l}\text { Developed a traditional processing method with four-stage } \\
\text { - } \text { - Maw charts; } \\
\text { rawe, wheat, finger millet and sorghum used as } \\
\text { - Shelf life is no longer than } 12 \mathrm{~h} \text { at room temperature storage. }\end{array}$ & $\begin{array}{l}\text { - } \quad \text { Borde has short shelf life; } \\
\text { - } \quad \text { Production process is time-consuming. }\end{array}$ & [29] \\
\hline $\begin{array}{l}\text { Microbial dynamics of } \\
\text { Borde fermentation }\end{array}$ & $\begin{array}{l}\text { Enterobacteriaceae and coliform decreased from } 10^{4} \mathrm{CFU} / \mathrm{mL} \text { to } \\
\text { below the detectable limit after } 8 \mathrm{~h} \text { of fermentation; } \\
\text { Lactic acid bacteria increased from } 10^{6} \text { to } 10^{9} \mathrm{CFU} / \mathrm{mL} \text { within } \\
24 \mathrm{~h} \text { of fermentation time; } \\
\text { Total fermentative yeast increased from } 10^{5} \text { to } 10^{7} \mathrm{CFU} / \mathrm{mL} \\
\text { after } 24 \mathrm{~h} \text { fermentation time. }\end{array}$ & $\begin{array}{l}\text { - Yeast biota is dominated by } \\
\text { Saccharomyces species; } \\
\text { - Keeping quality of Borde is very short. }\end{array}$ & [32] \\
\hline
\end{tabular}




\subsection{Shamita}

Shamita is another traditional low alcoholic beverage that is produced and consumed in different parts of Ethiopia. Roasted and ground barley is used as a major substrate during the fermentation stage [49]. This beverage also serves as a meal replacement for low income workers. Like other traditional Ethiopian fermented beverages (Tella and Borde), Shamita production does not require malt for the saccharification process [15].

To prepare Shamita, barley flour, salt, linseed flour, and a small amount of spice are mixed together with water to form a slurry liquid. As a starter culture, 1 to $2 \mathrm{~L}$ of previously produced slurry is added to the blend. The mixture is allowed to ferment overnight. Then, a small amount of bird's eye chili (C. annuum) is added and the beverage is ready to serve for consumption [34].

The first full-length article on Shamita was published by Ashenafi and Mehari [34], which focused on the enumeration of microorganisms in samples collected from different vendors. The report found that lactic acid bacteria and yeasts are the dominant microorganisms in Shamita. Four years later, Bacha et al. [14] studied Shamita fermentation microbial dynamics and the microbial load of raw materials. Their study showed that barley is the major source of fermentative microorganisms. The count of these fermentative microbes reached $10^{9} \mathrm{CFU} / \mathrm{mL}$ after a $24 \mathrm{~h}$ fermentation period. Later Tadesse et al. [49] studied the antimicrobial effect of lactic acid bacteria isolated from Shamita on pathogenic microorganisms. The isolated lactic acid bacteria were found to inhibit the growth of the Salmonella species S. flexneri, and S. aureus. Similar inhibition was observed for lactic acid bacteria isolated from Nigeria's oti-oka [8]. Additionally, the $\mathrm{pH}$, conductivity, salinity and TDS values of Shamita were 3.8, $8391 \mu \mathrm{s} / \mathrm{cm}, 4.6 \%$ and $4520 \mathrm{mg} / \mathrm{L}$, respectively [44].

\subsection{Korefe}

Korefe is a foamy fermented low alcoholic beverage popular in the northern and northwestern parts of Ethiopia. Similar to other Ethiopian fermented beverages, the fermentation system is natural and spontaneous. Barley, malted barley, "gesho"' (R. prinoides), and water are the major ingredients used to prepare this indigenous beverage [50].

The process of making Korefe begins by mixing "gesho" (R. prinoides) and water to produce "Tijit" in a traditional container locally known as "Gan" (Figure 2). The blend is left for $72 \mathrm{~h}$ to extract flavor, aroma, bitterness and fermenting microorganisms [15]. While that is happening, non-malted barley powder is mixed with water to form a dough. The dough is then baked to make unleavened bread locally called "Kitta". Then, "Tijit", a small sized "Kitta" and an adequate amount of water are mixed together and left to ferment for about $48 \mathrm{~h}$ [39]. The semisolid mixture obtained at this stage is locally called "Tenses". Subsequently, non-malted roasted barley powder, locally called "Derekot", is added to the previously prepared "Tenses". At this stage the blend is allowed to ferment for an additional $72 \mathrm{~h}$. Finally, water is added to the mixture in a ratio of 1:3. After another 2 to $3 \mathrm{~h}$ of further fermentation the Korefe is ready to be served [15].

According to Getnet and Berhanu [15], the titratable acidity, ethanol, and crude fat content of Korefe are $32 \mathrm{~g} / \mathrm{L}, 2.7 \%$ and $7.01 \%$, respectively. In addition, the $\mathrm{pH}$, conductivity, salinity and TDS values of Korefe are 3.7, $3199 \mu \mathrm{s} / \mathrm{cm}, 1.7 \%$ and $1610 \mathrm{mg} / \mathrm{L}$, respectively [44]. After $72 \mathrm{~h}$ of fermentation, lactic acid bacteria and yeast counts were more than $10^{9} \mathrm{CFU} / \mathrm{mL}$, whereas the enterobacteriaceae count was below the detectable limit due to the antagonistic effect of lactic acid bacteria [15]. 


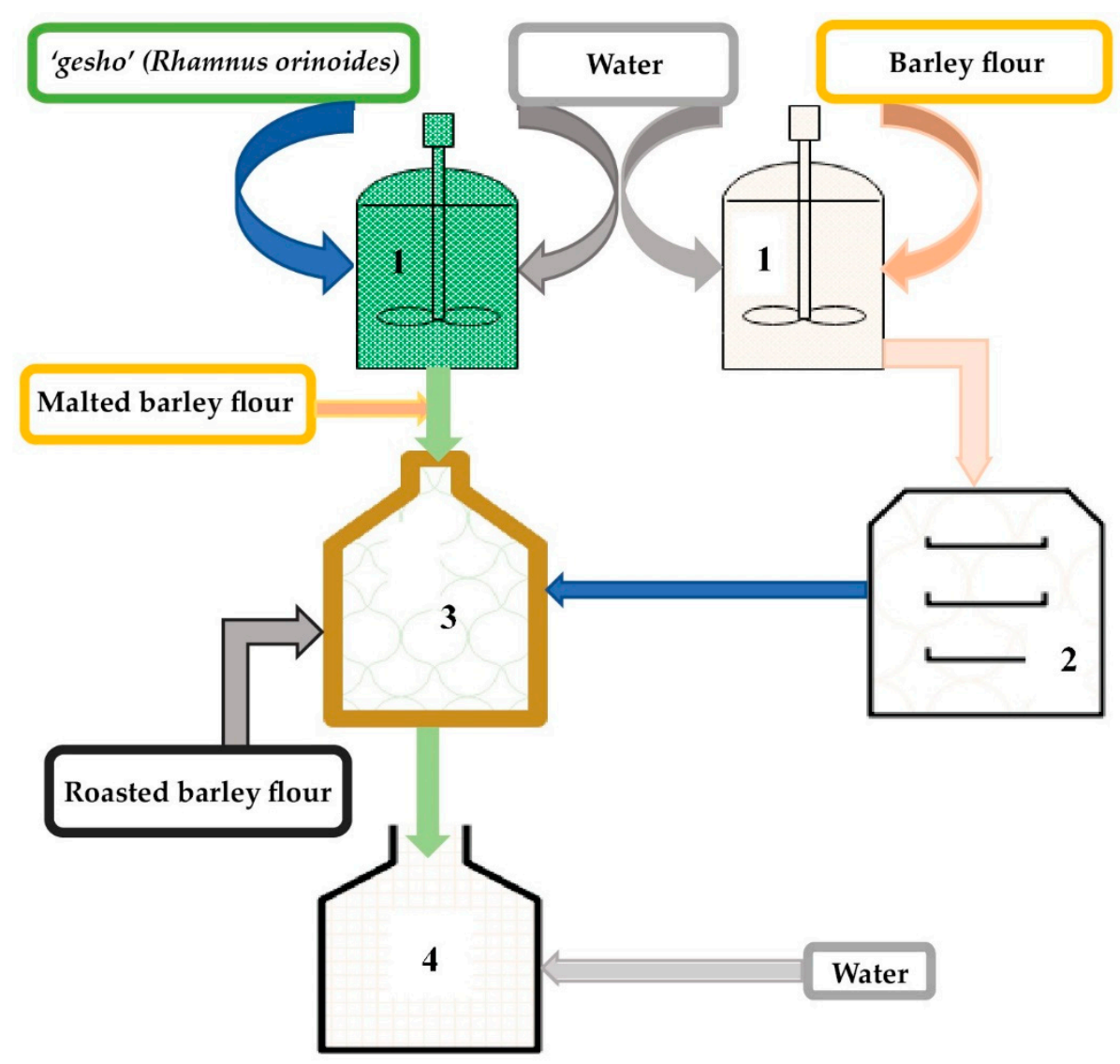

Figure 2. Korefe production process flow diagram: (1) mixer, (2) baking oven, (3) primary fermentation tank, (4) secondary fermentation tank.

\subsection{Cheka}

Cheka is a traditional low alcoholic fermented beverage commonly consumed in the southwestern parts of Ethiopia and particularly in Dirashe and the Konso district [36]. It is a cereal- and vegetable-based fermented low alcoholic beverage. Sorghum (S. bicolor), maize (Z. mays), finger millet (E. coracana), and vegetables such as leaf cabbage (Brassica spp.), moringa, (Moringa stenopetala), decne (Leptadenia hastata), and root of taro (Colocasia esculenta) are the main ingredients for Cheka preparation [17].

Worku et al. [35] reported a survey of raw materials and the production process of Cheka. According to their report, Cheka preparation starts by malting. The malt is prepared either from a single or a combination of the cereals listed above. Cabbage leaves and/or taro roots are cut into pieces and fermented anaerobically for about 4 to $6 \mathrm{~d}$ in a clean container. Then, a small amount of maize flour is added to the vegetable mixture and is fermented for an additional 2 to $3 \mathrm{~d}$. The fermented vegetable mixture is then ground, filtered, and mixed with fresh maize flour. The fermentation continues for another 12 to $24 \mathrm{~h}$. Then, water is added to the mixture and the mixture is allowed to ferment for one month. This fermented mixture is shaped into a dough ball, locally called "Gafuma", and cooked at a temperature of $96^{\circ} \mathrm{C}$. After cooling, the cooked "Gafuma" is mixed with an adequate amount of previously prepared malt. The mixture is then allowed to ferment for an extra $12 \mathrm{~h}$. This fermented mixture is locally called "Sokatet". At this stage of the process a very thick porridge, locally called "koldhumat", is prepared from maize flour. The prepared porridge is added to the vessel containing "Sokatet" with a sufficient amount of water. Finally, the mixture is left to ferment for another 4 to $12 \mathrm{~h}$ and served to consumers as Cheka.

Worku et al. [35] also published a paper that focused on the nutritional and alcohol content of Cheka. This report contained the physicochemical properties, ethanol, and methanol content of Cheka 
collected from Cheka producers. The average $\mathrm{pH}$, ethanol, iron (Fe) and calcium (Ca) contents of Cheka samples are $3.76,6 \%, 0.2 \mathrm{mg} / \mathrm{g}$ and $0.14 \mathrm{mg} / \mathrm{g}$, respectively.

\subsection{Keribo}

Keribo is another alcoholic traditional beverage consumed by many Ethiopians, especially by those who prefer low alcoholic drinks. The production process is relatively less complicated [51].

Abawari [34] reported the raw materials and processing conditions of Keribo. According to the report, making Keribo begins by mixing roasted barley with hot water. Then, the mixture is boiled for about $20 \mathrm{~min}$, after which the solid residue is removed by filtration. Subsequently, sugar and bakery yeast are added into the separated filtrate and left overnight to ferment. Finally, extra sugar is added to the mixture and the beverage is served to the consumer.

Abawari [16] published a second report that dealt with the microbial dynamics of Keribo fermentation. Based on the findings, average lactic acid bacteria, aerobic mesophilic bacteria, aerobic spore formers and yeasts counts were 2.70, 2.34, 4.96 and $2.01 \log \mathrm{CFU} / \mathrm{mL}$, respectively. However, the average enterobacteriaceae, staphylococci, and mold counts were below the detectable levels. Additionally, the shelf life of Kerbio is not more than two days at room temperature storage [40].

\section{Fruit-Based Traditional Alcoholic Beverages}

\section{1. $T e j$}

Tej is an Ethiopian wine that uses honey as a substrate and "gesho" (Rhamnus prinoides) as a source of bitterness. Previously, Tej was produced and consumed only for cultural festivities and for the royal families [52]. These days, Tej is a popular drink in rural, semi-urban, and urban areas of Ethiopia. It is produced and sold at the household level. The final product usually lacks consistency in quality due to differences in the manner of preparation and the ratio of ingredients used [21].

Ethiopia has the potential to produce 500,000 tons of bee honey annually. However, production has not surpassed $10 \%$ of that potential [53]. About $80 \%$ of the total honey produced in the country serves as raw material for producing Tej [54]. Traditionally, crude honey rather than refined honey is preferred for the production of $T e j$ due to the distinct sensorial properties that local consumers prefer [18].

The Tej making process begins by cleaning and drying the traditional fermenting container. Then, honey and water are mixed in a ratio of 1:3 and allowed to ferment for 2 to $3 \mathrm{~d}$. Afterwards, leaves and stems of "gesho" (R. prinoides) are boiled, cooled to room temperature and added to the previously fermented honey and water mixture. This mixture is allowed to ferment for 8 to 10 more days during the hot season or $20 \mathrm{~d}$ during the cold season [52]. After the intended period of fermentation, the product is ready to serve to the consumer in a special glass, locally known as "Berele".

The microorganisms involved in the fermentation process originate from the raw materials, equipment and utensils. Because of this, Tej fermentation is lengthy, spontaneous, and uncontrolled. Thus, the final product have inconsistent physicochemical properties, microbiological profile, and sensory attributes [21].

Good quality Tej is yellow, sweet, fizzy, and cloudy due to the presence of active yeasts [43]. The flavor of Tej is highly dependent on the type of honey used and amount of "gesho" (R. prinoides) added. Additionally, the diversity and population of microorganisms also contribute to the distinctive flavor of Tej [55]. Like Mexican pulque [12], the Ethiopian Tej's microorganism community is dominated by Lactic acid bacteria (LAB) and yeasts (Table 4). The shelf life and keeping quality of $T e j$ is very short [40]. 
Table 4. Physicochemical and microbiological properties of Tej, Ogol and Booka.

\begin{tabular}{|c|c|c|c|}
\hline Area of Investigation & Microbial and Physicochemical Properties & Concluding Remarks & References \\
\hline Flora of yeast and lactic acid bacteria of $T e j$ & $\begin{array}{l}\text { - S.cerevisiae }(25 \%), \text { K. bulgaricus }(16 \%) \text {, D. phaffi }(14 \%) \text { and K. } \\
\text { veronae }(10 \%) \text { are dominant yeast species; } \\
\text { Lactic biota is composed of Lactobacillus, Streptococcus, } \\
\text { Leuconostoc and Pediococcus species. }\end{array}$ & $\begin{array}{l}\text { Yeasts and LAB are among the } \\
\text { dominant microbes in Tej fermentation }\end{array}$ & [40] \\
\hline Physicochemical properties of $T e j$ & $\begin{array}{l}\text { - } \quad \mathrm{pH} \text { values of collected samples ranged between } 3.07 \text { and } 4.90 \text {; } \\
\text { - } \quad \text { Titratable acidity of samples ranged between } 1 \mathrm{~g} / \mathrm{L} \text { and } 1.03 \\
\mathrm{~g} / \mathrm{L} ; \\
\text { - } \quad \text { Total alcohol content ranged between } 2.7 \% \text { and } 21.7 \% \text {; } \\
\text { - } \quad \text { Average total dissolved solids (TDS) is } 387 \% \text {; } \\
\text { - } \quad \text { Average electrical conductivity is } 811 \mu \mathrm{s} / \mathrm{cm} ; \\
\text { - } \quad \text { Average Salinity is } 0.4 \mathrm{mg} / \mathrm{L} \text {. }\end{array}$ & $\begin{array}{l}\text { Natural and spontaneous fermentation } \\
\text { is a major source of physicochemical } \\
\text { variation in collected Tej samples }\end{array}$ & {$[18,44]$} \\
\hline Isolating fermentative yeast from $\mathrm{Ogol}$ & $\begin{array}{l}\text { - } \quad \text { S. cerevisiae is isolated from } O g o l \text { sample; } \\
\text { - } \quad \text { Isolated species produce } 16.5 \%(\mathrm{v} / \mathrm{v}) \text { ethanol; } \\
\text { - } \quad \text { Titratable acidity and } \mathrm{pH} \text { are } 60 \mathrm{~g} / \mathrm{L} \text { and 3.8, respectively. }\end{array}$ & $\begin{array}{l}\text { Isolated yeast from } O g o l \text { has the } \\
\text { potential to be used for ethanol } \\
\text { fermentation }\end{array}$ & [19] \\
\hline Physicochemical properties of Booka & $\begin{array}{l}\text { - } \quad \mathrm{pH} \text { value ranges from } 2.90-3.12 ; \\
\text { - } \quad \text { Moisture content- }-82.18 \% ; \\
\text { - } \quad \text { Ash content- } 0.82 \% ; \\
\text { - } \quad \text { Crude fat content- } 1.43 \% ; \\
\text { - } \quad \text { Total nitrogen- }-7.01 \% ; \\
\text { - } \quad \text { Total carbohydrate- } 8.56 \% ; \\
\text { - } \quad \text { ean alcoholic content }-1.53 \% \text {. }\end{array}$ & $\begin{array}{c}\text { Booka can be used as a } \\
\text { meal replacement }\end{array}$ & [20] \\
\hline
\end{tabular}




\subsection{Ogol}

Ogol is another traditional fermented honey wine beverage commonly consumed in the western part of Ethiopia. The preparation process starts by pulverizing the bark of the native tree "Mange" (B. unijungata). The pulverized bark, wild honey, and water are mixed in a container and the mixture is allowed to ferment for about two weeks. After completing the intended period of fermentation a small amount of water is added and the mixture is allowed to ferment anaerobically in a hot place for additional 12 to $36 \mathrm{~h}$. Finally, it is filtered through a clean cloth and served to consumers as Ogol [19].

\subsection{Booka}

Booka is a low alcoholic traditional beverage that is popular in southern Oromia, Ethiopia (Table 4). The preparation process is relatively simple and easily adaptable. First the bladder of a cow is carefully removed from a dressed carcass and cleaned properly to remove residue urine. Honey and water are added to the prepared cow bladder in a ratio of 1:4. After 2 to $3 \mathrm{~d}$ of fermentation, a small amount of honey is added to the mixture and it is left to ferment anaerobically for an additional $2 \mathrm{~d}$ [43]. After the fermentation process is completed, the filtrate is ready to be served to consumers as Booka. Good quality Booka is yellowish in color, sweet in taste, and attractive in odor [20].

\section{Nutritional Value, Function Properties and Safety Issues of Ethiopian Alcoholic Beverages}

The nutritional values of Ethiopian traditional alcoholic beverages can be seen in two ways. In low alcoholic beverages, the nutritional values are higher than their respective raw materials [29]. The main justification forwarded by authors is the live microorganisms present in these beverages $[14,34,47]$. In high alcoholic beverages, the nutritional values are lower than that of low alcoholic traditional beverages [1,18]. As shown in Table 5, Borde, Shamita and Cheka have a good nutritional value compared to that of high alcoholic beverages like Tella and Tej. As the fermentation continues, from the fermentation dynamics point of view, only limited microorganisms withstand the adverse environmental effect of the growth medium. Thus, the microorganisms that do not cope with the new environment will be lysed and become a source of protein for cell maintenance for the surviving species. This analysis works even better in natural, spontaneous and uncontrolled fermentation systems. Hence, this competition in return decreases the nutritional value of the beverages while increasing secondary metabolites like ethanol [56-58].

The functional properties of the beverage are manifested in the content of total polyphenols (TP) and antioxidant activity (AA) [59]. These polyphenols and antioxidants have a health-promoting effect by scavenging free radicals and regulating metabolism [60]. Many Ethiopian alcoholic beverages have good TP and AA values (Table 5). The phenolic content of Tella is greater than that of Korefe and Tej [61]. Even though there are many factors responsible for this difference, raw materials, and especially the amount of gesho added to the mixture, take the lion's share of the contribution [38].

The safety issues of Ethiopian traditional alcoholic beverages should be understood from the perspective of microorganism growth, higher alcohol and fluoride contents. Although the presence of a large amount of live fermentative microorganisms in low alcoholic traditional beverages contributes to their good nutritional value, there are major concerns related to food safety [17]. The microbiological safety issues were discussed in the previous section of this paper. This section focuses only on food safety issues related to higher alcohol and fluoride content. Higher alcohols contents of Isobutanol, 1-Butanol, 2-Butanol and 1-Propanol can be called collectively fusel oil or fuselol [62]. Fusel oil in a minute quantity contributes to the good flavor of the product. However, if it is consumed at a level above $1000 \mathrm{~g} / \mathrm{hL}$ of pure alcohol, fusel oil is harmful for health [63]. The higher methanol content in traditional beverages also has a negative health impact [44]. Most of the time methanol is formed due to natural, spontaneous and uncontrolled fermentation [18]. As shown in Table 5, the methanol content of Tella and Cheka is very much lower than the maximum standard set by the European Union (EEC No 1576/89). Since Ethiopia is located in the region of the Great Rift Valley, fluoride ion 
concentration is another important food safety concern in traditional alcoholic beverages. A level of fluoride ions above $1.5 \mathrm{mg} / \mathrm{L}$ in the beverage creates dental and skeletal fluorosis [64]. Traditional beverages collected near Rift Valley localities showed a higher fluoride ion concentration (Table 5).

Table 5. Nutritional value, functional properties and safety issues of Ethiopian alcoholic beverages.

\begin{tabular}{|c|c|c|c|c|}
\hline Beverages & Nutritional Value & $\begin{array}{l}\text { Functional Properties } \\
\text { (Average Values) }\end{array}$ & $\begin{array}{c}\text { Higher Alcohol and Fluoride } \\
\text { Ion (Average Values) }\end{array}$ & References \\
\hline Tella & $\begin{array}{c}\text { Total protein }-0.4 \% \\
\text { Carbohydrate- }-1.98 \%\end{array}$ & $\begin{array}{c}\mathrm{TP}\left(\mu \mathrm{g} \mathrm{mL} \mathrm{mL}^{-1)}-232.40\right. \\
\mathrm{AA}\left(\mu \mathrm{g} \mathrm{mL} \mathrm{mL}^{-1)}-296.00\right. \\
\text { Folate }\left(\mathrm{mgcg}^{-1}\right)-0.093\end{array}$ & $\begin{array}{c}\text { Fusel oil }(\mathrm{ppm})-51 \\
\text { Methanol }(\mathrm{ppm})-41.5 \\
\text { Fluoride ion }(\mathrm{mg} / \mathrm{L})-4.26\end{array}$ & {$[1,46,61,65]$} \\
\hline Borde & $\begin{array}{c}\text { Total protein-9.55\%, } \\
\text { Crude fat- } 6.88 \%, \\
\text { Total ash- }-3.66 \%\end{array}$ & $\begin{array}{c}\mathrm{TP}\left(\mu \mathrm{g} \mathrm{mL} L^{-1)}-9.50\right. \\
\mathrm{AA}\left(\mu \mathrm{g} \mathrm{mL} \mathrm{m}^{-1)}-198.5\right.\end{array}$ & Fluoride ion $(\mathrm{mg} / \mathrm{L}) — 4.95$ & {$[29,33,39,65]$} \\
\hline Shamita & $\begin{array}{c}\text { Total protein }-10.37 \% \\
\text { Crude fat- } 6.85 \% \\
\text { Total ash }-3.46 \%\end{array}$ & - & Fluoride ion $(\mathrm{mg} / \mathrm{L})-5.21$ & {$[33,34,65]$} \\
\hline Korefe & - & $\begin{array}{l}\mathrm{TP}\left(\mu \mathrm{g} \mathrm{mL}^{-1)}-167.60\right. \\
\mathrm{AA}\left(\mu \mathrm{g} \mathrm{mL} \mathrm{mL}^{-1)}-278.13\right.\end{array}$ & Fluoride ion $(\mathrm{mg} / \mathrm{L})-1.39$ & {$[63,65]$} \\
\hline Cheka & $\begin{array}{c}\text { Total protein-3.83\% } \\
\text { Crude fat- }-1.49 \% \\
\text { Carbohydrate- }-16.59 \% \\
\text { Total ash- }-0.79 \%\end{array}$ & - & Methanol(ppm)-271.55 & [17] \\
\hline Keribo & - & $\begin{array}{l}\mathrm{TP}\left(\mu \mathrm{g} \mathrm{mL} \mathrm{mL}^{-1)}-12.65\right. \\
\mathrm{AA}\left(\mu \mathrm{g} \mathrm{mL} \mathrm{m}^{-1)}-64.66\right.\end{array}$ & - & [38] \\
\hline $\mathrm{Tej}$ & $\begin{array}{c}\text { Total protein }-0.35 \% \\
\text { Crude fat }-0.35 \% \\
\text { Carbohydrate }-3.58 \% \\
\text { Total ash }-0.04 \%\end{array}$ & $\begin{array}{c}\mathrm{TP}\left(\mu \mathrm{g} \mathrm{mL} \mathrm{mL}^{-1)}-197.00\right. \\
\mathrm{AA}\left(\mu \mathrm{g} \mathrm{mL}^{-1)}-240.37\right.\end{array}$ & $\begin{array}{l}\text { Fusel oil }(\mathrm{ppm})-205.08 \\
\text { Fluoride ion }(\mathrm{mg} / \mathrm{L})-6.68\end{array}$ & {$[18,21,38,61,65]$} \\
\hline Bokaa & $\begin{array}{c}\text { Moisture content- } 82.18 \% \\
\text { Ash content- } 0.82 \% \\
\text { Crude fat content- }-1.43 \% \\
\text { Total Nitrogen- } 7.01 \%\end{array}$ & - & - & [20] \\
\hline
\end{tabular}

$\overline{\mathrm{TP}}$ in gallic acid equivalent (GAE); $\mathrm{AA}$ in ascorbic acid equivalent (AAE); —values not available in the literatures.

\section{Conclusions and Future Perspectives}

The most commonly produced and consumed Ethiopian traditional alcoholic beverages are Tella, Borde, Shamita, Korefe, Cheka, Keribo, Tej, Ogol and Booka. The ingredients, ratios, procedures and equipment used to prepare these beverages vary from place to place, but they all are produced through natural and spontaneous fermentation processes. Low alcoholic Ethiopian beverages have a higher nutritional value. Thus, they can be used as a meal replacement. These traditional alcoholic beverages also contain a significant amount of total polyphenols and antioxidants. The alcohol content and $\mathrm{pH}$ values of these beverages range from $1.53-21.7 \%$ and $2.9-4.9$, respectively. As the fermentation continues, counts of lactic acid bacteria and yeasts species flourish while mesophilic aerobic bacteria and coliform counts decrease significantly. The source of microorganisms responsible for fermentation is mainly from the ingredients and utensils. These traditional alcoholic beverages show inconsistent quality within and between productions, and have a short shelf life. This is due to the high number of live cells present in freshly produced beverages.

Until now, research on Ethiopian traditional fermented beverages has mainly focused on the identification of raw materials and traditional processing methods. Moreover, microbial characterization and microbial dynamics have been reported for the last two decades. All of the reports have used culture-dependent phenotypic characterization. Hence, the current findings lack the completeness needed to lead these traditional beverages, which hold equal local market share with commercial products, into large-scale production. Thus, we find that future research has to shift its gear to a higher level by studying microbial metagenomics, starter culture development, rheological study, shelf life extension, process modification, kinetics, modeling and optimization.

Author Contributions: Conceptualization, writing-original draft preparation, rewriting, E.G.F.; conceptualization, writing-review and editing, supervision, S.A.E.; writing-review and editing, H.D.D.; 
writing—review and editing, D.W.D.; writing—review and editing, supervision, J.-H.S. All authors have read and agreed to the published version of the manuscript.

Funding: This work was supported by the Strategic Initiative for Microbiomes in Agriculture and Food (Grant No. 918010-4), Ministry of Agriculture, Food, and Rural Affairs, South Korea.

Acknowledgments: The Authors would like to acknowledge the Addis Ababa Science and Technology University, Addis Ababa University, and Kyungpook National University.

Conflicts of Interest: The authors declare no conflict of interest.

\section{References}

1. Tekle, B.; Jabasingh, S.; Fantaw, D.; Gebreslassie, T.; Rao, S.; Baraki, H.; Gebregziabher, K. An insight into the Ethiopian traditional alcoholic beverage: Tella processing, fermentation kinetics, microbial profiling and nutrient analysis. LWT Food Sci. Technol. 2019, 107, 9-15. [CrossRef]

2. Tamang, J. Diversity of fermented beverages and alcoholic drinks. In Fermented Foods and Beverages of the World; Tamang, J., Kailasapathy, K., Eds.; Taylor and Francis Group: New York, NY, USA, 2010; pp. 86-117.

3. Marshall, E.; Mejia, A. Traditional Fermented Food and Beverages for Improved Livelihoods; FAO: Rome, Italy, 2011.

4. $\quad$ CSA. Agricultural Sample Survey 2015/2016 (2009 E.C.). Volume I. Report on Area and Production of Major Crops (Private Peasant Holdings, Meher Season); Addis: Ababa, Ethiopia, 2016.

5. WHO. Global Status Report on Alcohol and Health 2018; World Health Organization: Geneva, Switzerland, 2018.

6. Tamang, J.P.; Thapa, N.; Bhalla, T.C. Ethnic Fermented Foods and Beverages of India. In Ethnic Fermented Foods and Alcoholic Beverages of Asia, 1st ed.; Tamang, J., Ed.; Springer India: New Delhi, India, 2016; pp. 17-72.

7. Lyumugabe, F.; Kamaliza, G.; Bajyana, E.; Thonart, P. Microbiological and physico-chemical characteristic of Rwandese traditional beer Ikigage. Afr. J. Biotechnol. 2010, 9, 4241-4246.

8. Ogunbanwo, S.; Ogunsanya, B. Quality assessment of oti-oka like beverage produced from pearl millet. J. Appl. Biosci. 2012, 51, 3608-3617.

9. Namugumya, B.; Muyanja, C. Traditional processing, microbiological, physiochemical and sensory characteristics of kwete, a Ugandan fermented maize based beverage. Afr. J. Food Agric. Nutr. Dev. 2009, 9, 1046-1059.

10. Kirui, M.; Alakonya, A.; Talam, K.; Tohru, G.; Bii, C. Total aflatoxin, fumonisin and deoxynivalenol contamination of busaa in Bomet county, Kenya. Afr. J. Biotechnol. 2014, 13, 2675-2678.

11. Kim, E.; Chang, Y.; Ko, J.; Jeong, J. Physicochemical and microbial properties of the Korean traditional rice wine, Makgeolli, supplemented with banana during fermentation. Prev. Nutr. Food Sci. 2013, 18, 203-209. [CrossRef]

12. Valadez-Blanco, R.; Bravo-Villa, G.; Santos-Sánchez, N.; Velasco-Almendarez, S.; Montville, T. The Artisanal Production of Pulque, a Traditional Beverage of the Mexican Highlands. Probiotics Antimicrob. Proteins 2012, 4, 140-144. [CrossRef]

13. Abegaz, K. Isolation, characterization and identification of lactic acid bacteria involved in traditional fermentation of Borde, an Ethiopian cereal beverage. Afr. J. Biotechnol. 2007, 6, 1469-1478.

14. Bacha, K.; Mehari, T.; Ashenafi, M. Microbiology of the fermentation of 'shamita', a traditional Ethiopian fermented beverage. Ethiop. J. Sci. 1999, 22, 113-126. [CrossRef]

15. Getnet, B.; Berhanu, A. Microbial dynamics, roles and physico-chemical properties of 'Korefe', a traditional fermented Ethiopian beverage. Biotechnol. Int. 2016, 9, 56-175.

16. Abawari, R. Microbiology of keribo fermentation; an Ethiopian tradtional fermented beverage. Pak. J. Biol. Sci. 2013, 16, 1113-1121. [PubMed]

17. Worku, B.; Gemede, H.; Woldegiorgis, A. Nutritional and alcoholic contents of cheka: A traditional fermented beverage in Southwestern Ethiopia. Food Sci. Nutr. 2018, 6, 2466-2472. [CrossRef] [PubMed]

18. Bahiru, B.; Mehari, T.; Ashenafi, M. Chemical and nutritional properties of 'tej', an indigenous Ethiopian honey wine: Variations within and between production units. J. Food Technol. Afr. 2001, 6, 104-108.

19. Teramoto, Y.; Sato, R.; Ueda, S. Characteristics of fermentation yeast isolated from traditional Ethiopian honey wine, ogol. Afr. J. Biotechnol. 2005, 4, 160-163.

20. Elema, T.; Olana, B.; Elema, A.; Gemeda, H. Processing methods, physical properties and proximate analysis of fermented beverage of honey wine Booka in Gujii, Ethiopia. J. Nutr. Food Sci. 2018, 8, 2. [CrossRef]

21. Nemo, R.; Bacha, K. Microbial, physicochemical and proximate analysis of selected Ethiopian traditional fermented beverages. LWT_Food Sci. Technol. 2020, 131, 109713. [CrossRef] 
22. Herman, J.; Maynard, A. Wine. In Microbial Technology: Fermentation Technology; Peppler, H., Perlman, D., Eds.; Academic Press Inc.: London, UK, 1979; Volume 2, p. 132.

23. Pederson, S. Microbiology of Food Fermentation; AVI Publishing Co. Inc.: Westport, CT, USA, 1979.

24. Steinkraus, K. Indigenous Fermented Foods in Which Ethanol Is a Major Product, 2nd ed.; Taylor \& Francis: New York, NY, USA, 1996; pp. 365-402.

25. Amabye, T. Evaluation of phytochemical, chemical composition, antioxidant and antimicrobial screening parameters of rhamnus prinoides (Gesho) available in the market of mekelle, tigray, Ethiopia. Nat. Prod. Chem. Res. 2015, 3, 6. [CrossRef]

26. Abegaz, B.; Kebede, T. Geshoidin: A bitter principle of Rhamus Prinoides and other constituents of the leaves. Bull. Chem. Soc. Ethiop. 1995, 9, 107-114.

27. Alemu, H.; Abegaz, B.; Bezabih, M. Electrochemical behaviour and voltammetric determination of geshoidin and its spectrophotometric and antioxidant properties in aqueous buffer solutions. Bull. Chem. Soc. Ethiop. 2007, 21, 89-204.

28. FAO. Traditional Fermented Food and Beverage for Improved Livelihoods; A Global Perspective; FAO: Rome, Italy, 2012.

29. Abegaz, K.; Beyene, F.; Langsrud, T.; Narvhus, J. Indigenous processing methods and raw materials of 'Borde', an Ethiopian traditional fermented beverage. J. Food Technol. Afr. 2002, 7, 59-64. [CrossRef]

30. Andualem, B.; Shiferaw, M.; Berhane, N. Isolation and characterization of saccaromyces cervisiae yeasts isolates from 'Tella' for beer production. Annu. Res. Rev. Biol. 2017, 15, 1-12. [CrossRef]

31. Tekluu, B.; Gebremariam, G.; Aregai, T.; Harikrishna, R. Determination of alcoholic content and other parameters of local alcoholic beverage (Tella) at different stages in Gondar, Ethiopia. Int. J. IT Eng. Appl. Sci. Res. 2015, 4, 37-40.

32. Bacha, K.; Mehari, T.; Ashenafi, M. The microbial dynamics of 'Borde' fermentation, a traditional Ethiopian fermented beverage. Ethiop. J. Sci. 1998, 21, 195-205. [CrossRef]

33. Ashenafi, M.; Mehari, T. Some microbiological and nutritional properties of 'Borde' and 'Shamita', traditional Ethiopian fermented beverages. Ethiop. J. Health Dev. 1995, 9, 105-110.

34. Abawari, R. Indigenous Processing Methodsand Raw Materials of Keribo: An Ethiopian Traditional Fermented Beverage. J. Food Resour. Sci. 2013, 2, 13-20.

35. Worku, B.; Woldegiorgis, A.; Gemeda, H. Indigenous processing methods of Cheka: A traditional fermented beverage in southwestern Ethiopia. J. Food Process. Technol. 2015, 7, 1.

36. Desta, B.; Melese, G. Determination of protein value and alcoholic content in locally prepared different types of Cheka at different stages using CHNS elemental analyzer and specific gravity methods. Am. J. Appl. Chem. 2019, 7, 168-174. [CrossRef]

37. Lee, M.; Regu, M.; Seleshe, S. Uniqueness of Ethiopian traditional alcoholic beverage of plant origin, Tella. mboxemphJ. Ethn. Foods. 2015, 2, 110-114. [CrossRef]

38. Debebe, A.; Chandravanshi, B.; Redi-Abshiro, M. Total contents of phenolics, flavonoids, tannins and antioxidant capacity of selected traditional ethiopian alcoholic beverages. Bull. Chem. Soc. Ethiop. 2016, 30, 27-37. [CrossRef]

39. Tafere, G. A review on Traditional Fermented Beverages of Ethiopian. J. Nat. Sci. Res. 2015, 5, $94-103$.

40. Bahiru, B.; Mehari, T.; Ashenafi, M. Yeast and lactic acid flora of tej, an indigenous Ethiopian honey wine: Variations within and between production units. Food Microbiol. 2006, 23, 277-282. [CrossRef] [PubMed]

41. Berza, B.; Wolde, A. Fermenter Technology Modification Changes Microbiological and Physicochemical Parameters, Improves Sensory Characteristics in the Fermentation of Tella: An Ethiopian Traditional Fermented Alcoholic Beverage. J. Food Process. Technol. 2014, 5, 1-8.

42. Berhanu, A. Microbial profile of Tella and the role of gesho (Rhamnus prinoides) as bittering and antimicrobial agent in traditional Tella (Beer) production. Int. Food Res. J. 2014, 21, 357-365.

43. Yohannes, T.; Melak, F.; Siraj, K. Preparation and physicochemical analysis of some Ethiopian traditional alcoholic beverages. Afr. J. Food Sci. 2013, 7, 399-403. [CrossRef]

44. Tadesse, S.; Chandravanshi, B.; Ele, E.; Zewge, F. Ethanol, methanol, acid content and other quality parameters of Ethiopian traditional fermented, distilled and factory produced Ethiopian traditional fermented, distilled and factory produced. SINET Ethiop. J. Sci. 2017, 40, 16-35.

45. Fite, A.; Tadesse, A.; Urga, K.; Seyoum, E. Methanol, fusel oil and ethanol contents of some Ethiopian traditional alcoholic beverages. SINET Ethiop. J. Sci. 1991, 14, 19-27. 
46. Getaye, A.; Tesfaye, D.; Zerihun, A.; Melese, F. Production, optimization and characterization of Ethiopian traditional fermented beverage 'Tella' From Barley. J. Emerg. Technol. Innov. Res. 2018, 5, 797-799.

47. Abegaz, K.; Langsrud, T.; Beyene, F.; Narvhus, J. The effect of technological modifications on the fermentation of 'Borde', an Ethiopian tradtional fermented cereal beverage. J. Food Technol. Afr. 2004, 9, 3-12.

48. Tadesse, G.; Ashenafi, M.; Ephraim, E. Survival of E. coli O157: H7 Staphylococcus aureus, Shigella flexneri and Salmonella spp. in fermenting 'Borde', a traditional Ethiopian beverage. Food Control 2005, 16, 189-196. [CrossRef]

49. Tadesse, G.; Ephraim, E.; Ashenafi, M. Assessment of the antimicrobial activity of lactic acid bacteria isolated from Borde and Shamita, traditional Ethiopian fermented beverages, on some food-borne pathogens and effect of growth medium on the inhibitory activity. Internet J. Food Saf. 2005, 4, 13-20.

50. Gebreyohannes, G.; Welegergs, B. Determination of alcoholic content and other parameters of locally preparedalcoholic beverages (korefe and tej) at different stages in Gondar town. Int. J. Integr. Sci. Technol. 2015, 4, 1-4.

51. Dibaba, K.; Tilahun, L.; Satheesh, N.; Geremu, M. Acrylamide occurrence in Keribo: Ethiopian traditional fermented beverage. Food Control 2018, 86, 77-82. [CrossRef]

52. Vogel; Gobezie. Indigenous fermented foods in which ethanol is a major product. In Handbook of Indigenous Fermented Foods, 2nd ed.; Steinkraus, K., Ed.; Marcel Dekker Inc.: New York, NY, USA, 1996; pp. 367-369.

53. Gebretsadik, T.; Negash, D. Honeybee production system, challenges and opportunities in selected districts of gedeo zone, southern nation, nationalities and peoples regional state, Ethiopia. Int. J. Res. 2016, 4, 49-63.

54. Gebremedhin, G.; Tadesse, G.; Kebede, E. Physiochemical characteristics of honey obtained from traditional and modern hive production systems in Tigray region, northern Ethiopia. Momona Ethiop. J. Sci. 2013, 5, 115-128. [CrossRef]

55. Lemi, B. Microbiology of Ethiopian Traditionally Fermented Beverages and Condiments. Int. J. Food Microbiol. 2020, 2020, 1478536.

56. Lucke, F. Indigenous lactic acid bacteria of various food commodities and factor affecting their growth. In Lactic Acid Bacteria: Current Advances in Metabolism, Gentics and Application, 1st ed.; Bozoglu, T., Ray, B., Eds.; Springer: Berlin, Germany, 2015.

57. Djeni, T.; Karen, H.; Ake, K.; Laurent, S. Microbial diversity and metabolite profiles of palm wine produced from three different palm tree species in Côte d'Ivoire. Sci. Rep. 2020, 10, 1715. [CrossRef]

58. Cason, E.; Mahlomaholo, B.; Taole, M.; Abong, G.; Vermeulen, J.; Smidt, O.; Vermeulen, M.; Steyn, L. Bacterial and fungal dynamics during the fermentation process of sesotho, a traditional beer of Southern Africa. Front. Microbiol. 2020, 11, 1451. [CrossRef]

59. Cory, H.; Passarelli, S.; Szeto, J.; Tamez, M.; Mattei, J. The Role of polyphenols in human health and food systems: A mini-review. Front. Nutr. 2018, 5, 87. [CrossRef]

60. Ganesan, K.; Xu, B. A critical review on polyphenols and health benefits of black soybeans. Nutrients 2017, 9, 455. [CrossRef]

61. Shewakena, S.; Chandravanshi, B.; Debeb, A. Levels of total polyphenol, flavonoid, tannin and antioxidant activity of selected Ethiopian fermented traditional beverages. Int. Food Res. J. 2017, 24, 2033-2040.

62. Lachenmeier, D.; Haupt, S.; Schulz, K. Defining maximum levels of higher alcohols in alcoholic beverages and surrogate alcohol products. Regul. Toxicol. Pharmacol. 2008, 50, 313-321. [CrossRef] [PubMed]

63. Lee, S.; Shin, J.; Lee, K. Determination of fusel oil content in various types of liquor distributed in Korea Pre-treatment of samples GC analysis of fusel oil. Korean Soc. Food Preserv. 2017, 24, 510-516. [CrossRef]

64. Fawell, J.; Bailey, K.; Chilton, J.; Dahi, E.; Fewtrell, L.; Magara, Y. Fluoride in Drinking Water; World Health Organization and IWA Publishing, Inc.: London, UK, 2006.

65. Belete, Y.; Chandravanshi, B.S.; Zewgea, F. Levels of the fluoride ion in six traditional alcoholic fermented beverages commonly consumed in Ethiopia. Fluoride 2017, 50, 79.

Publisher's Note: MDPI stays neutral with regard to jurisdictional claims in published maps and institutional affiliations. 